\title{
QUANTITATIVE ANALYSIS OF THE NEURONS FROM THE MYENTERIC PLEXUS IN THE ILEUM OF RATS SUBMITTED TO SEVERE PROTEIN DEFICIENCY
}

\author{
Neide Martins Moreira, Catchia Hermes, Carla Simone Leite de Almeida, Evelyne Cruz Santana, \\ Débora de Mello Gonçales Sant'Ana, Eduardo José de Almeida Araújo
}

\begin{abstract}
The effects of protein malnutrition on the quantitative aspects of the myenteric plexus in the ileum of adult Rattus norvegicus were assessed. Thirty 90 -day-old rats were divided into two groups: Control Group (CG, n=15) and Experimental Group (EG, n=15). The CG received 26\% protein chow and the EG received $4 \%$ protein chow for 90 days. At the end of the experiment, the animals from the CG weighed 369.63 \pm 26.33 , and the ones from the EG 215.34 \pm 56.31 . The ileum was submitted to Giemsa, NADH- and NADPH-diaphorase technique in order to evidence nervous cells in the whole-mount preparations. Animals from the EG presented a $41.75 \%$ body weight loss in relation to the CG as well as $17.6 \%$ length reduction for the ileum-jejunum. Moreover, the organ was $41 \%$ lighter for the EG. Giemsa-stained neurons were $17.02 \%$ more concentrated in the EG ( $p>0.05)$. NADH-diaphorase-stained neurons were $26.6 \%$ more concentrated in the EG $(p<0.05)$, while the NADPH-diaphorase were $26.28 \%$ more concentrated in this group $(p<0.05)$.
\end{abstract}

KEY WORDS: protein malnutrition, rat ileum, enteric neurons.

\begin{abstract}
Análise quantitativa dos neurônios do plexo mientérico do íleo de ratos submetidos a intensa carência de proteínas

Resumo - Avaliou-se o efeito da desnutrição protéica sobre o número de neurônios mientéricos do íleo de ratos adultos. Foram utilizados 30 animais (90 dias de idade), divididos em dois grupos: controle (GC, n=15) e experimental (GE, n=15), sendo oferecido ao GC ração com teor protéico de $26 \%$ e, para o GE, ração com $4 \%$ de

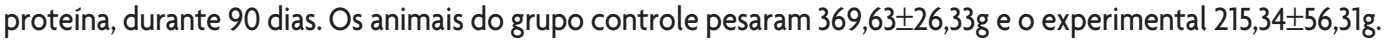
Preparados de membrana do íleo foram submetidos à técnica de Giemsa, NADH- e NADPH-diaforase. Os animais do GE apresentaram perda de peso de $41,75 \%$, em relação ao GC e redução do comprimento do jejuno-íleo de 17,6\%, além disso, o órgão apresentou-se $41 \%$ mais leve no GE. Os neurônios corados com a técnica de Giemsa apresentaram-se 17,02\% mais concentrados no GE ( $p>0,05)$. Os neurônios NADH-diaforase apresentaram-se $26,60 \%$ mais concentrados no GE $(p<0,05)$. E os neurônios NADPH-diaforase apresentaramse $26,28 \%$ mais concentrados neste grupo $(p<0,05)$.
\end{abstract}

PALAVRAS-CHAVE: má nutrição protéica, íleo, rato, neurônio entérico.

The digestive tube presents its own nervous system named enteric nervous system (ENS), from the esophagus through the end of the anal canal. The ENS independently and integratively coordinates all the digestive processes (nutrient absorption, secretion, and intestinal motility) even though it differs from the sympathetic and parasympathetic nervous systems with respect to its structure ${ }^{1,2}$. The ENS is constituted by groups of neurons organized in ganglions and interconnected by nervous fiber bundles constituting the intramural plexuses. Among these, myen- teric and submucous plexuses are the most important for the coordination of the digestive activities. Comprehending the functioning and alterations of the myenteric plexus is aimed in the scientific studies ${ }^{1,2}$. Morphofunctional alterations in the enteric plexuses may occur due to age and unbalanced diets. Thus, studies inducing nutritional deficiency may aid explaining common clinical signs on the malnourished such as abdominal pain, constipation, fecal incontinence, diarrhea, and malabsorption ${ }^{3}$.

Malnutrition is a set of pathological conditions and

\footnotetext{
Paper presented as part of the first author's graduation monograph to the UNIPAR Nursing Departament; Experimental Neurogastroenterology Laboratory - UNIPAR; Umuarama, PR Brazil. Financial Support: UNIPAR.

Received 28 September 2007, received in final form 11 February 2008. Accepted 6 March 2008.

Dr. Eduardo José de Almeida Araújo - Experimental Neurogastroenterology Lab. Universidade Paranaense (UNIPAR) - Praça Mascarenhas de Moraes $s / n$ - 87502-210 Umuarama PR - Brasil.
} 
may differently occur resulting in either reversible or irreversible organic alteration ${ }^{4}$. All normal metabolic processes demand protein participation and all tissues are affected by a state of protein malnutrition; however, it does not present the same speed and type of modification. The former tissues suffering alterations caused by protein deficiency are those which present high cell renovation rates such as the intestinal mucosa, as the latter are those presenting low cell renovation rates such as the nervous sys$t^{5} \mathrm{~m}^{5}$. A number of articles demonstrate that the small intestine in face of malnutrition situations suffer functional and morphological alterations. Hypoplasia and hypotrophy of the mucosa in malnourished rats ${ }^{6,7}$ and the increase of the myenteric neuronal density while reducing the protein level on the chow to $8 \% \%^{6,8-13}$.

As there is a gap in the literature with respect to the effects of severe malnutrition (4\%) on the enteric neurons, this paper analyzed the neuronal density of the neurons from the myenteric plexus in the ileum of malnourished rats subjected to a hypoproteic diet (4\%) for 90 days.

\section{METHOD}

The experimental protocol was previously approved by the UNIPAR (Universidade Paranaense) Ethics Committee on Animal Experimentation.

Thirty male 90-day-old Wistar rats $(303.8 \pm 29.73 \mathrm{~g})$ were divided into two groups: Control Group (CG; $n=15$ ) and Experimental Group (EG; $n=15$ ), housed in individual cages with constant temperature in dark/bright $(12 / 12 \mathrm{hr})$ cycle, receiving water and chow ad libitum. The CG was maintained on $26 \%$-protein-commercial NUVILAB ${ }^{\circledR}$ (Paraná, Brazil) chow, the GE was maintained on $4 \%$-protein- prepared chow ${ }^{14}$.

Animals from both groups were weighed and monitored regarding their water and chow intake weekly.

After 90 days, the animals were anesthetized after a 12-hr fasting according to the following protocol: Acepran (1.26 mL/ $\mathrm{Kg})+$ Ketamine $10 \%(1.26 \mathrm{~mL} / \mathrm{Kg})+$ Xilazine $2 \%(0.42 \mathrm{~mL} / \mathrm{Kg})$ e Atropine $1 \%(0.22 \mathrm{~mL} / \mathrm{Kg})$ intramuscularly administered ${ }^{15}$. Laparotomy was carried out and the ileum-jejunum from each animal was removed, weighed, and measured with a millimeter ruler.

The terminal ileums from 5 other rats were washed with a $0.9 \%$ $\mathrm{NaCl}$ solution and immersed in a formal acetic fixation solution for 48 hour, then dissected and stained with Giemsa solution ${ }^{16}$.

The ileums from other 5 animals from each group were submitted to the NADH-diaphorase histochemistry. Segments were first filled and washed twice (10 min) with Krebs solution ( $\mathrm{pH} 7.3)$, second immersed in $0.3 \%$ Triton X-100 for 5 min in Krebs and washed (2x10 min, each), then immersed for $45 \mathrm{~min}$ in an incubation medium containing in every $100 \mathrm{~mL}: 25 \mathrm{~mL}$ of stock solution of the Nitro Blue Tetrazolium (NBT, Sigma, St. Louis, USA); $25 \mathrm{~mL} 0.1 \mathrm{M}$ phosphate buffer, $\mathrm{pH} 7.3 ; 50 \mathrm{~mL}$ of distilled water, and $5 \mathrm{mg}$ of $\beta$-NADH (Sigma, Steinheim, Germany) ${ }^{17}$.

The ileums of other 5 animals from each group were washed and filled with phosphate buffer ( $\mathrm{pH} 7.4$ ) fixed with $4 \%$ parafor- maldehyde (Merck, Darmstad, Germany) in 0.1M PBS (pH 7.4) for 30 min, immersed in Triton X-100 (Sigma, St. Louis, USA) in 0.3\% $0.01 \mathrm{M}$ PBS ( $\mathrm{pH} 7.4)$, then washed (10 x $10 \mathrm{~min}$, each) in PBS and submersed for $60 \mathrm{~min}$ in an incubation medium containing in every $200 \mathrm{ml}$.: $200 \mathrm{ml}$ tris-HCl (GibcoBRL, New York, EUA); 0.05g NBT (Sigma, Steinheim, Germany); 0.1 g $\beta$-NADPH (Sigma, Steinheim, Germany), and $0.6 \mathrm{~mL}$ Triton $\mathrm{X}-100^{18}$. Reactions were monitored in a stereoscopic microscope.

The whole-mount preparations from the different techniques were dissected under a transillumination stereomicroscope by removing the mucosa and the submucosa. Then, they were dehydrated in ascending series of ethanol, diaphanized in xilol and mounted among slides and coverslips with Permount ${ }^{\circledR}$ synthetic resin (Fischer Chemical, New Jersey, USA).

Sampling was carried out in order to quantify the myenteric neurons. Forty microscopic fields were counted on the following regions: mesenteric, intermediary, and antimesenteric on all animals and techniques on both groups. A MOTIC B1 microscope (40x objective lens) was used for counting. All the neurons from each field were counted considering the half-neurons from each alternate field. The area on each microscopic field was $0.21 \mathrm{~mm}^{2}$.

All data were first submitted to the Kolmogorov-Smirnov test in order to verify the distribution type. Thus, data from the normal distribution were expressed as mean \pm standard deviation. $T$-test for independent samples was used to compare information between the CG and the EG. p values lower than 0.05 were considered statistically significant.

\section{RESULTS}

The weight from the experimental rats decreased (215.34 $\pm 56.31 \mathrm{~g})$ in comparison with the control group $(369.63 \pm 26.33 g)(p<0.05)$ in the end of the experiment.

Length and body weight of the ileum-jejunum was significantly low for the EG as described on Table 1.

Results from the quantitative analysis of the neurons by three different techniques are described on Table 2.

\section{DISCUSSION}

The comparison of the final body weight between the CG and the EG demonstrated a difference of $41.75 \%$ $(p<0.05)$. Studies with different experimental models of malnutrition carried out with rats with different ages also demonstrated retarded body weight gain for the animals while fed with a $8 \%$ hypoprotein diet $t^{6,8,9,10,13}$. Body weight reduction was probably a result of the adaptation to the protein malnutrition due to lower nutrient availability, as well as lower development of fat and lean mass in these animals. Such adaptation possibly demonstrates a mean of maintaining the metabolism of the noble tissues already constituted (such as the nervous tissue) in order to keep them alive longer so that the animal is able to find a new source of food fulfilling the demand of its organism ${ }^{19}$. 
Table 1. Length and weight of the ileum-jejunum of rats normally fed (Control Group - CG) and subjected to protein desnutrition (Experimental Group - EG).

\begin{tabular}{lcc}
\hline Parameter & $\mathrm{GC}(\mathrm{n}=15)$ & $\mathrm{EG}(\mathrm{n}=15)$ \\
\hline Length $(\mathrm{cm})$ & $105.00 \pm 5.58^{\mathrm{a}}$ & $86.55 \pm 13.84^{\mathrm{a}}$ \\
Weight $(\mathrm{g})$ & $9.82 \pm 1.75^{\mathrm{b}}$ & $5.79 \pm 1.14^{\mathrm{b}}$ \\
\hline
\end{tabular}

Data presented as mean \pm standard deviation. Means followed by the same letter on the same row showed significant difference $\left({ }^{a} p=0.001\right.$; ${ }^{b} \mathrm{p}<0.0001$.

Table 2. Populational density of myenteric neurons of the ileum of rats normally fed (Control Group - CG) and subjected to protein desnutrition (Experimental Group - EG) in an area of $25.2 \mathrm{~mm}^{2}$.

\begin{tabular}{lcc}
\hline Technique & CG $(n=5)$ & EG $(n=5)$ \\
\hline Giemsa & $6,648.6 \pm 790.2$ & $8,012.0 \pm 1,368.4$ \\
NADH-diaphorase & $2,383.4 \pm 721.84 \mathrm{a}$ & $3,247.0 \pm 337.15 \mathrm{a}$ \\
NADPH-diaphorase & $1,083.4 \pm 170.37 \mathrm{~b}$ & $1,469.6 \pm 231.92 \mathrm{~b}$ \\
\hline
\end{tabular}

Data presented as mean \pm standard deviation. Means followed by the same letter on the same row showed significant difference $\left({ }^{\mathrm{a}} \mathrm{p}=0.0416\right.$; ${ }^{b} \mathrm{p}=0.0170$

Protein level reduction not only commits body development but also organs and system ${ }^{6}$. They respond differently to malnutrition effects and the digestive tube is usually committed by the amino-acid deficiency ${ }^{5}$.

The ileum-jejunum was $17.6 \%$ smaller and $41 \%$ lighter for the EG which demonstrates that the protein level reduction committed the normal development of the organ $(\mathrm{p}<0.05)$. While studying the protein availability reduction to $8 \%$ for rats during pregnancy, lactation, and weaning until their 60 -day-old, it was observed a $45.21 \%$ reduction on the ileum length and wall thickness ${ }^{6}$. The small size of the organ may be considered as an adaptive response either to the decreased amount of chow or the reduced metabolic rate ${ }^{19}$. The reduction of the organs is believed to be a reflex of its own tissue alterations as they may present different degrees of commitment according to their own structural and cellular organization ${ }^{6}$.

By comparing the total population density of the stained neurons with Giemsa technique, neurons were expected to be $17.60 \%$ more concentrated as the organ was $17.60 \%$ smaller; however, the concentration was $17.02 \%$ - a very close value not statistically significant - indicating that there were not any reductions on the total population of neurons. Previous studies carried out on malnourished animals have also showed the preservation of total neuronal population in the ileum of rats ${ }^{6,9,10}$. Other experiments on different segments in the small intestine did not evidence any myenteric neuron losses ${ }^{12,20}$ as well when rats were submitted to different protein level malnutri- tion. The protein level was probably sufficient to ensure neuron survival in this study reinforcing the hypothesis that the reduction of chow during aging has demonstrated to be a neuronal population protection factor providing a longevity increase $e^{21,22}$.

Positive NADH-diaphorase neurons from the EG were $26.60 \%$ more concentrated. Malnutrition does not increase the number of total neurons as it is determined since the embryonic life, therefore, the neurons which were not from this class started to do it after malnutrition $^{13}$. Subpopulation of positive NADH-d neurons on CG was $35.85 \%$ of the total neuronal population and $40.53 \%$ on the EG. As the neurons present the highest metabolic activity ${ }^{23}$, protein reduction seemed to have activated neuronal metabolism in this study. Rats submitted to $8 \%$ protein malnutrition for 120 days have also presented an increase with respect to this neuronal subpopulation in the duodenum ${ }^{12}$ and $96.7 \%$ higher in the jejunum ${ }^{13}$. On the other hand, long-term diet restriction demonstrated that positive NADH-diaphorase subpopulation in the ileum decreased for the 24-month-old animals without reducing total population. The authors associate such reduction to lower enzymatic activity relating to NADH-diaphorase as though it is not associated with neuronal death ${ }^{22}$.

NADPH-diaphorase neurons were $26.28 \%$ more concentrated than those in the CG. Although NADPH-d histochemistry does not evidence neurons the overall neuronal population, it has been largely used for evidencing neurons presenting the NO synthase responsible for the production of nitric oxide ${ }^{24}$ - an important mediator of the intestinal relaxing. The nitrergic subpopulation on the CG was $16.3 \%$ and $18.34 \%$ on the EG, demonstrating amplification. As the studied organ was $17.60 \%$ smaller, the natural concentration increase of the subpopulation would be $17.60 \%$; however, $26.8 \%$ was verified suggesting a $9.2 \%$ neuron increase expressing the NOS. It has been studied that the positive NADPH-d neurons are invulnerable to cellular death in animals under controlled diet ${ }^{22}$. Studies carried out on young and old rats submitted to chow intake restrictions showed that the NADPH-diaphorase neurons reduced in average of $50 \%$ during the aging period when they were normofed in the CG. Nevertheless, when they received a $50 \%$ normal diet, there were not any neuronal reductions showing that there were not any losses due to aging. In the same study, animals fed with just a $25 \%$ normal diet did not present any neuronal losses at 30 months of age as well 22 .

In this study, we observed that $4 \%$ protein malnutrition for 90 days of age resulted in the decrease of the body weight, as well as the organ size and weight. When comparing the neuronal density, we observed that malnutrition did not cause in any losses with respect to the 
overall neuronal population, and resulted in an increase of the positive NADH-diaphorase and NADPH-diaphorase neuron subpopulations possibly reflecting the organ functional adaptation to protein deficiency.

\section{REFERENCES}

1. Brehmer A. Structure of enteric neurons. New york: Springer, 2006:1-5.

2. Furness JB, Costa M. The enteric nervous system. New York: Churchill Livingstone, 2006:1-28.

3. Wade PR, Cowen T. Neurodegeneration: a key factor in the ageing. Gut Motil 2004;16:19-23.

4. Oliveira FLG. Aspectos clínicos e laboratoriais In Nobrega FJ (Ed). Distúrbios da nutrição: na infância e na adolescência. Rio de Janeiro: Revinter, 2007:195-198.

5. Deo MG. Cell biology of protein-calorie malnutrition. Wld Rev Nutr Diet 1978;32:49-95.

6. Torrejais MM, Natali MRM, Conegero CI, Miranda-Neto MH. Effects of proteic desnutrition after breast-feeding on the morphology of the intestinal wall and enteric neurons of the ileum of rats. Rev UNIMAR 1995; 17:315-327.

7. Sarni ROS, Souza FIS. Tratamento da desnutrição energético-protéico moderado e grave In Nobrega FJ (Ed). Distúrbios da nutrição: na infância e na adolescência. Rio de Janeiro: Revinter, 2007:210.

8. Natali MRM, Miranda-Neto MH. Effects of maternal proteic undernutrition on the neurons of the myenteric plexus of duodenum of rats. Arq Neuropsiquiatr 1996;54:273-279.

9. Meillus M, Natali MRM, Miranda-Neto MH. Study of the myenteric plexus of the ileum of rats subjected to proteic undernutrition. Rev Chil Anat 1998;16:9-14.

10. Fiorini A, Molinari SL, Natali MRM, Miranda-Neto MH. Quantitative morphological analysis of the myenteric neurons of the ileum in rats under experimental desnutrition. Acta Scientiarium 1999;21:404-423.

11. Natali MRM, Miranda-Neto MH, Orsi AM. Ultrastructural features of myenteric ganglia of adult Wistar rats (Rattus norvegicus). Anat Histol Embryol 2000;29:393-397.
12. Natali MRM, Miranda-Neto MH, Orsi AM. Morphometry and quantification of the myenteric neurons of the duodenum of adult rats fed with hypoproteic chow. Inter J Morphology 2003;21:273-277.

13. Zanin SMT, Molinari SL, Sant'Ana DMG, Miranda-Neto MH. Neurônios NADH-diaforase positivos do jejuno de ratos (Rattus norvegicus) desnutridos. Arq Ciênc Saúde Unipar 2003;61:650-653.

14. Araújo EJA, Sant'Ana DMG, Molinari SL, Miranda-Neto MH. Biometric and food consumption parameters of rats subjected to hypoproteic and hypocaloric diet. Arq Ciên Vet Zool Unipar 2005;8:133-140.

15. Pachaly JR, Sant'Ana DMG, Araújo EJA, Ciffoni EMG, Acco A. Anesthesia of Wistar rats (rattus norvegicus) with allometrically scaled doses of ketamine xylazine acepromazine and atropine-prelimanary report. Arq Ciênc Vet Zool UNIPAR 2003;3:195-197.

16. Barbosa AJA. Técnica histológica para gânglios nervosos intramurais em preparados espessos. Rev Bras Pesq Med Biol 1978;11:95-97.

17. Gabella G. Detection of nerve cells by a histochemical technique. Experientia 1969;23:218-219.

18. Scherer-Singler U, Vicent SR, Kimura H, Megeer EG. Demonstration of a unique population of neurons with NADPH-diaphorase histochemistry. J Neurosci Methods 1983;9:229-234.

19. Araújo AEJ, Sant'Ana DMG, Molinari SL, Miranda-Neto MH. Quantitative study of the myenteric plexus of the descending colon of young rats subjected to sintese protein deficiency. Int J Morphol 2006;24:591-597.

20. Natali MRM, Molinari SL, Valentini LC, Miranda-Neto MH. Morphoquantitative evaluation of the duodenal myenteric neuronal population in ratos fed with hypoproteic ration. Biocell 2004;29:39-46.

21. Johnson RJR, Schemann M, Santer RM, Cowen T. The effects of age on the overal population and on sub-populations of myenteric neurons in the rat smal intestine. J Anat 1998;192:479-488.

22. Cowen T, Johnson RJ, Soubeyre V, Santer RM. Restricted diet rescues rat enteric motor neurones from age related cell death. Gut Online 2000 47:653-660.

23. Sant'Ana DMG, Miranda-Neto MH, Souza RR, Molinari SL. Morplological and quantitative atudy of the myenteric plexus of the ascending colon of rats subjcted to proteic desnutrition. Arq Neuropsiquiatr 1997;55:687-695.

24. Young HM, Furness JB, Shuttleworth CWR, Bredt DS, Snyder SH. Co-localization of nitric oxide synthase immunoreactivity and NADPH-diaforase in neurons of the guinea-pig intestine. Histochimitry 1992;97:375-378 